\title{
Protein-energy interrelationships in growth and lactation of cattle and sheep
}

By W. H. Broster, National Institute for Research in Dairying, Shinfield, Reading, $R G 2, A T$

\section{Introduction}

Flexibility is needed in planning rations for livestock to meet the fluctuations in the economic situation, highlighted for instance by the recent scarcity and high price of protein-rich foods. Tables of requirements tend to treat protein and energy separately, whereas their joint effects on production are becoming more apparent. The 'requirements' concept could with advantage include that of 'responses', i.e. change in output with change in input of either protein or energy or both. The Agricultural Research Council (1965) made some progress in this direction, but a thorough-going analysis of the independent and joint effects of protein and energy intakes on production is still lacking. This paper sketches some of the main relationships involved.

The level of energy intake affects protein utilization in the monogastric animal (Munro, 1964), and Miller \& Payne (1964) distinguished three types of response curve: response to (a) increment of food at constant protein: energy ratio, (b) additional protein at constant energy intake and (c) additional energy at constant protein intake. A similar approach is required for the ruminant. Type (a) responses constitute broadly the total plane of nutrition effects and are of considerable agricultural interest (Thomson \& Aitken, 1959, for sheep; Allden, 1970, for young stock generally; Broster, 1972a, for lactating cows), but a wide range of independent variation of protein and energy intakes (type (b) and (c) responses) is necessary to analyse fully protein-energy interrelationships.

\section{Responses of cattle and sheep to protein and energy intakes \\ Response in growth \\ Broster and his colleagues (Bailey \& Broster, 1957; Broster, Tuck \& Balch, 1964; Broster, Tuck, Smith \& Johnson, 1969) demonstrated curvilinear responses in the rate of live-weight gain to increased protein intakes at constant energy intake in cattle of various ages, and a response to increased energy intakes at constant protein intake. A fall in growth occurred at very high protein intakes (Broster et al. 1969). Contemporaneously with the more fragmentary evidence of Broster and his colleagues, Elliott, Reed \& Topps (1964) in an elegant experiment with three levels}


each of protein $(\mathrm{P})$ and energy $(\mathrm{E})$ produced a multiple regression equation of the general form:

Growth $=b_{1} P+b_{2} E+b_{3} P E+b_{4} P^{2}+a\left(a, b_{1} \ldots b_{4}\right.$ are constants, where $b_{4}$ is negative in fact...

Broster, Broster \& Smith (I970) produced a similar expression from the combined results of all their experiments.

Stobo, Roy \& Gaston $\left({ }^{9} 6_{7}\right)$ reported that in the ruminating calf a given amount of protein supports a greater body-weight gain with a greater efficiency of food utilization when supplied with a large compared to a small amount of energy. Stobo \& Roy (1973) generalized their evidence, and agreed broadly with the above interpretation.

Comprehensive studies by Andrews \& Ørskov ( $1970 a, b$ ) and Ørskov, MacDonald, Fraser \& Corse (197r) demonstrated comparable input:output relationships of growth to protein and energy intakes in lambs to those observed by Elliott et al. (1964) in cattle. Robinson \& Forbes (1970a), with lambs, and Robinson \& Forbes (I967), with pregnant ewes, produced a relationship:

Growth $=b_{1} P+b_{2} P^{2}+K$ for the protein $(P)$ effect on growth at constant energy

intake (where $\mathrm{K}, \mathrm{b}_{1} \ldots \mathrm{b}_{2}$ are constants) ...

Sykes \& Field (1972) also reported a beneficial effect of additional protein at constant low-energy intake in reducing body-weight loss in the pregnant ewe and increasing birth weight in the lamb.

\section{Response in body composition}

An interspecies comparison which includes ruminants and monogastric animals (see analyses by Kielanowski, 1972; Breirem \& Homb, 1972) shows a general agreement (though individual pieces of evidence may disagree on particular points) that additional protein at constant energy intake increases the bone and protein content of the body while decreasing the fat content. Increasing energy intake while keeping the protein intake constant increases fat deposition. Andrews \& Orskov $(1970 a, b)$ found increasing the energy intake at each percentage level of protein in the ration also increased body protein. These effects apply across the trends of increasing fat and falling protein content in the body as the animal ages. A constant terminal body composition in lambs at about $50 \mathrm{~kg}$ live weight, although there was variation in nutritional regime during growth, has been suggested by Orskov et al. (1971).

\section{Response in lactation}

Since the early classical work (see review by Broster, 1972b) the influence of protein and energy intakes per se on milk output have not received the attention they deserve, particularly for long-term effects. In early lactation protein and energy are mobilized from the body to support milk production. The extent and use of protein reserves has been neglected in research (Paquay, De Baere \& Lousse, 1972). Evidence for short-term effects (see reviews by Rook, 1961; Balch, 1972; Broster, $1972 b$ ) shows a curvilinear response in yield of both milk and solids-not-fat to 
variation of intake of either protein or energy, with energy as the more potent factor. There is some evidence, though not conclusive, of an increased response to a protein increment at high-compared to low-energy intake (Rook, $196 \mathrm{r}$; Broster et al. 1969 ; Gordon \& Forbes, 1970); a negative effect of very high levels of protein as in growth has not been demonstrated. However Tyrrell, Moe \& Flatt (1970) concluded from calorimetric evidence that excess protein reduced the efficiency of energy utilization. Gordon \& Forbes (1970) observed a greater partition of nutrients into milk rather than into body reserves under these conditions. Balch \& Campling ( $196 \mathrm{I}$ ) demonstrated a curvilinear response in body-milk nitrogen to $\mathrm{N}$ intake. Body $\mathrm{N}$ was affected much more than the milk $\mathrm{N}$ content. The response in solidsnot-fat content referred to above involved casein content of the milk at low levels of intake but non-protein $\mathrm{N}$ at high levels.

Robinson \& Forbes (1970b) reported positive correlations of milk $\mathrm{N}$ and also change of body $\mathrm{N}$ content with protein and energy intakes. The relationships were expressed in a quadratic equation.

\section{Further aspects of animal performance in response to protein and energy intakes}

The joint and specific roles of dietary protein and energy in the enhanced growth rate that occurs on re-alimentation after a period of underfeeding is not clear (Allden, 1970), nor are their effects on fertility in the cow (Broster, 1973). For maintenance of body-weight and zero-N retention Elliott \& Topps (1963a,b; 1964) and Robinson $\&$ Forbes (I 966 ) have shown for cattle and sheep that the protein requirements are dependent on the level of energy supplied.

Frequently, but not always, additional $\mathrm{N}$ has been found to increase voluntary intake of poor-quality roughages (Campling, Freer \& Balch, 1962). Similar effects have also been found with good-quality roughages (Murdoch, 1962; Broster et al. 1964). No further improvement occurred with more than 6-10 per cent protein in the dry matter of the rations of cattle (Andrews, Escuder-Volonte, Curran \& Holmes, 1972), but Ørskov et al. (1971) reported benefits when the ration contained up to r6-20 per cent for lambs. Elliott \& Topps ( $1963 a, b)$ observed that the minimum protein content of the ration to induce maximum intake varied with the type of roughage; Elliott (1967) and Crabtree \& Williams (1971) linked both concentrates and protein intake to roughage-intake capacity. The equation derived by Elliott ( 1967 ) was:

voluntary intake $=a+b_{1} C+b_{2} C^{2}+b_{3} P+b_{4} P^{2}+b_{5} C P,(C$, concentrates intake and other terms as p. I 16 ) ... With more protein in the ration, more concentrates were eaten and a higher peak intake occurred, at least for sheep; the critical range for cattle was not reached.

Bines (I97I) has described a model relating intake of dry matter and digestible energy to energy density in the ration and to energy requirements.

\section{Mathematical evaluation}

\section{Interpretation of responses}

The quadratic equation frequently used to describe the relationship between 


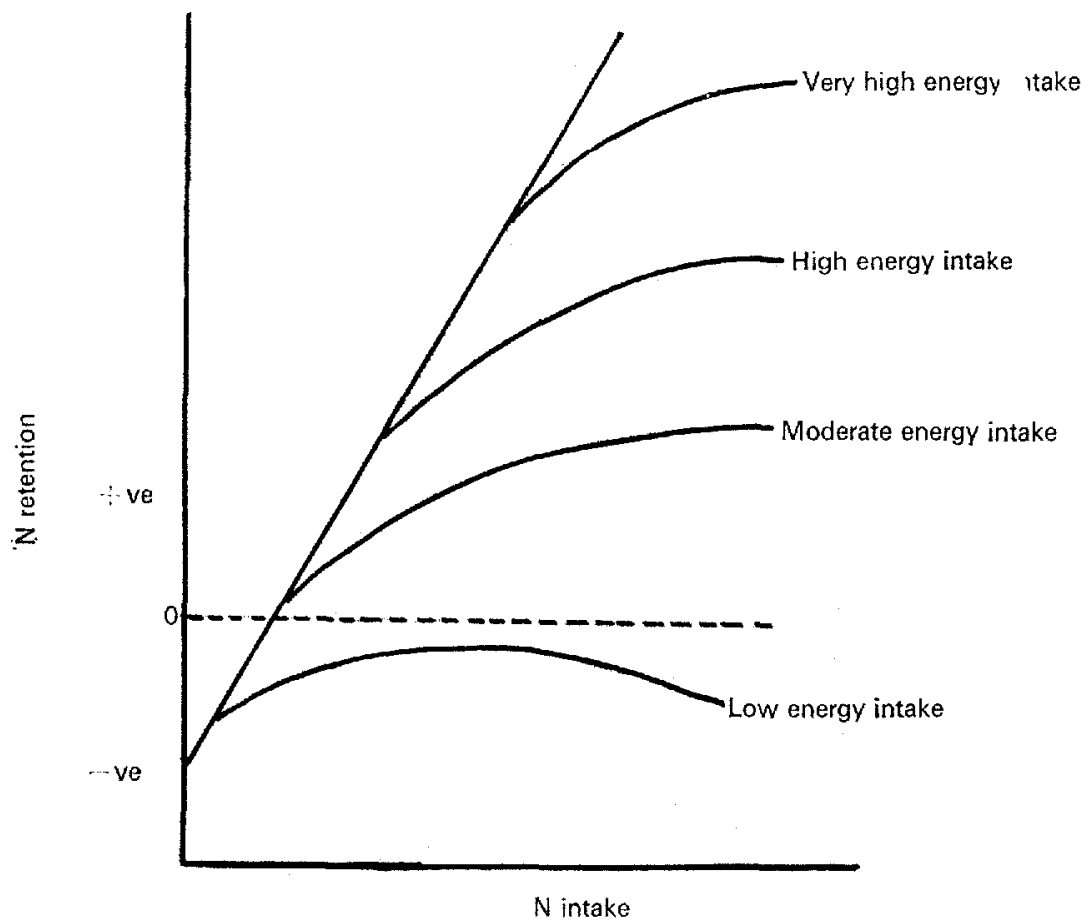

Fig. 1. Diagrammatic model of the relationship between intake of nitrogen and $\mathrm{N}$ balance or bodyweight change of heifers receiving various amounts of energy (after Balch, 1967)

protein-energy input and output includes an additive plus a multiplicative beneficial effect from the two nutrients and, as $b_{4}$ is universally found to be negative, an adverse effect from excessive protein intakes. Balch (1967) has provided a diagrammatic model of the relationship (Fig. I). At intakes which are low relative to energy intake, protein is used with high and constant efficiency (P term in equation ( $\mathrm{I})$ ). It is the limiting factor to output; additional energy has no benefit. At somewhat higher relative protein intakes efficiency of utilization falls at a given energy intake but an increasing response to additional energy occurs (PE term in equation ( 1 )), leading to continued maximal efficiency of utilization of larger amounts of protein at higher energy intakes. Progressively as the level of protein increases so successive energy levels of intake become inadequate and the response to yet more protein declines and finally becomes negative $\left(\mathrm{P}^{2}\right.$ term in equation (I)). Output from protein intake depends on level of energy supplied, and vice versa, over the normal range of intakes.

Differentiation of the equation leads to statements of change in output with change in input, maximum and optimum outputs (the two may not coincide) and rate of tissue deposition (Ørskov et al. I971).

The equation can be reconstructed in terms of protein and energy needs for particular rates of growth (Stobo \& Roy, 1973, see Fig. 2), and also for milk-N output in ewes (Robinson \& Forbes, $1970 b$ ). Minimum intakes of protein and energy 


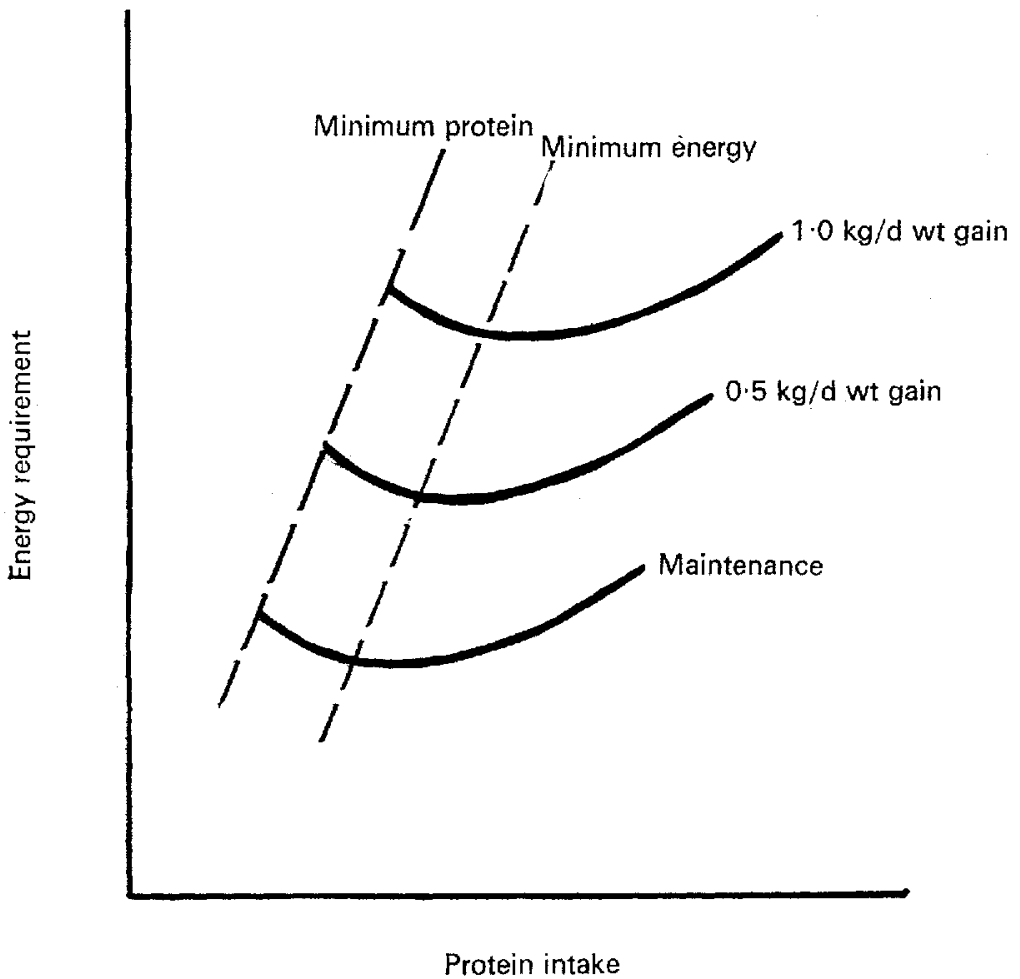

Fig. 2. Diagrammatic representation of the amounts of digestible protein and digestible energy required for various rates of growth in young cattle (after Stobo \& Roy, 1973)

can be distinguished but the minimum for one is not compatible with minimum for the other for a particular output for which various ratios can be chosen. This has economic repercussions: these have been discussed with regard to milk production in the cow by Jawetz (1960) and for least-cost rations by Dent \& Casey (1967).

The statistical significance and predictive value of the variables and derived variables in the equation are rarely given yet this is a necessary adjunct to their evaluation. Broster et al. (1970) reported that the $\mathrm{PE}$ and $\mathrm{E}$ terms were the most effective in accounting for the variance in growth, also the percentage so accounted for was less for small than for large heifers.

\section{Effect on digestibility}

It is pertinent in the interpretation of responses to protein and energy intakes to recall their effects on digestibility e.g., Head (1953) and further references quoted by Broster et al. (1969) and Broster (1972a). Additional protein increases the apparent digestibility of protein in the ration, additional energy depresses it. The substitution of readily available carbohydrate for roughage increases apparent digestibility of protein but metabolic faecal losses of $\mathrm{N}$ are high in ruminants. An increase in readily available carbohydrates in the ration increases total organic-matter digestibility but reduces that of fibre, whereas additional protein benefits organic-matter and 
fibre digestibilities; additional roughage content has the opposite effect to that of protein.

There is disagreement on the effect of gross level of feeding, for example, with cattle, Reid, Moe \& Tyrrell (1966) found dry-matter digestibility to decline with increase in intake; the effect was more pronounced with rations of high-compared to low-energy density; Wiktorsson (I97I) did not find this effect. The composition rather than the level of intake may be the key factor here.

Rumen fermentation is discussed elsewhere in this Symposium.

\section{Effect of the source of energy and protein}

The preceding section and other examples from practical situations present limitations to an oversimplified general application of the above model. Thus at low planes of nutrition Elliott \& Topps $(1963 a, b ; 1964)$ noted that $\mathrm{N}$ retention declined in sheep as the level of roughage in the ration increased at constant total digestible nutrient intake; at higher levels of feeding oat hulls replacing starch, without change of digestible organic matter or protein intake, did not affect $\mathrm{N}$ retention (Broster, Smith \& Broster, 1972); sugars added to generous hay and concentrate rations increased rate of live-weight gain in heifers and also in lactating cows whilst increasing the solids-not-fat content of the milk but not the milk yield (Broster, Sutton \& Smith, 1968); substitution of ground straw for barley in ad lib. diets of constant protein content did not affect the carcass composition of beef cattle (Swan, 1969). Similarly for protein sources, Balch \& Bines (I973) observed equal N retention in cattle from supplements of groundnut meal and urea at constant digestible-energy intake; but Tagari, Ben Gedalya, Shevach \& Bondi (1971) found the relative rating of lucerne and soya-bean-meal proteins for sheep depended on the form and level of energy in the ration. Fish-meal protein supported a greater growth rate in yearling cattle than groundnut meal at low but not high levels of protein supplementation in otherwise constant diets (Broster \& Tuck, I967). Black (1972) found a similar result but also observed that the proteins affected the digestibility of the energy in the ration. The available evidence indicates that for low-yielding cows the source of protein has no effect on milk production at normal rates of feeding (Broster, 1972b). There appears to be little evidence on interrelationships of fat and protein in the diets.

\section{Conclusion}

Only joint statements of protein and energy requirements are meaningful and there is some scope for interchange of the one for the other. In both applied and basic research, comprehensive studies of protein and energy need to progress simultaneously. Also the parallel effects for ruminant and simple-stomached animals should be explored. With energy being the principal quantitative limiting factor to output it is desirable to examine how far requirements for other nutrients can be calibrated in terms of the animal's energy requirements (Kleiber, 1959; Balch, 1967). Rates of responses differ between cattle and sheep: this needs investigating further.

Careful scanning of the relevant literature by $\mathrm{Mr} \mathrm{N}$. W. Briggs is gratefully acknowledged. 


\section{REFERENCES}

Agricultural Research Council (1965). The Nutrient Requirements of Farm Livestock. No. 2 Ruminants. London: Agricultural Research Council.

Allden, W. G. (1970). Nutr. Abstr. Rev. 40, 1167.

Andrews, R. P., Escuder-Volonte, J., Curran, M. K. \& Holmes, W. (1972). Anim. Prod. I5, 167.

Andrews, R. P. \& Orskov, E. R. (1970a). F. agric. Sci., Camb. 75, 1 I.

Andrews, R. P. \& Orskov, E. R. (1970b). F. agric. Sci., Camb. 75, 19.

Bailey, G. L. \& Broster, W. H. (1957). F. agric. Sci., Camb. 49, 435.

Balch, C. C. (1967). Wld Rev. Anim. Prod. 3, 84.

Balch, C. C. (1972). In Handbuch der Tierernährung Vol. 2, p. 259 [W. Lenkeit, K. Brierem and E. Crasemann, editors]. Hamburg: Paul Parey.

Balch, C. C. \& Bines, J. A. (1973). Br. F. Nutr. 29, 457.

Balch, C. C. \& Campling, R. C. (I961). F. Dairy Res. 28, I57.

Bines, J. A. (г971). Proc. Nutr. Soc. 30, i 16.

Black, J. L. (1972). Bienn. Rep. natn. Inst. Res. Dairy. (In the Press.)

Breirem, K. \& Homb, T. (1972). In Handbuch der Tierernährung Vol. 2, p. 547 [W. Lenkeit, K. Breirem and E. Crasemann, editors]. Hamburg: Paul Parey.

Broster, W. H. ( (972a). Dairy Sci. Abstr. 34, 265.

Broster, W. H. (1972b). In Handbuch des Tierernährung Vol. 2, p. 292 [W. Lenkeit, K. Breirem and E. Crasemann, editors]. Hamburg: Paul Parey.

Broster, W. H. (1973). Vet. Rec. (In the Press.)

Broster, W. H., Broster, V. J. \& Smith, T. (1970). Bienn. Rep. natn. Inst. Res. Dairy. p. 82.

Broster, W. H., Smith, T. \& Broster, V. J. (I972). Bienn. Rep. natn. Inst. Res. Dairy. (In the Press.)

Broster, W. H., Sutton, J. D. \& Smith, T. (I968). Ann. Rep. natn. Inst. Res. Dairy. p. 70.

Broster, W. H. \& Tuck, V. J. (1967). Ann. Rep. natn. Inst. Res. Dairy. p. 44.

Broster, W. H., Tuck, V. J. \& Balch, C. C. (1964). F. agric. Sci., Camb. 63, 5 I.

Broster, W. H., Tuck, V. J., Smith, T. \& Johnson, V. W. (I969). F. agric. Sci., Camb. 72, I3.

Campling, R. C., Freer, M. \& Balch, C. C. (1962). Br.\%. Nutr. 16, 1 5 .

Crabtree, J. R. \& Williams, G. L. (197 I). Anim. Prod. 13, 83.

Dent, J. B. \& Casey, H. (1967). Linear programming and animal nutrition. London: Crosby Lockwood \& Son Ltd.

Elliott, R. C. (1967). F. agric. Sci., Camb. 68, 375 .

Elliott, R. C., Reed, W. D. C. \& Topps, J. H. (Ig64). Br. F. Nutr. 18, 5 I9.

Elliott, R. C. \& Topps, J. H. (1963a). Br. F. Nutr. 17, 539.

Elliott, R. C. \& Topps, J. H. (1963b). Anim. Prod. 5, 269.

Elliott, R. C. \& Topps, J. H. (1964). Br. $\mathcal{F}$. Nutr. 18, 245.

Gordon, F. J. \& Forbes, T. J. (1970). 7. Dairy Res. 37, 48 I.

Head, M. J. (1953). F. agric. Sci., Camb. 43, 281.

Jawet's, M. B. (1960), Ұ. agric. Econ. 14, 1.

Kielanowski, J. (I972). In Handbuch der Tierenährung Vol. 2, p. 528 [W. Lenkeit, K, Breirem and E. Crasemann, editors]. Hamburg: Paul Parey.

Kleiber, M. (1959). In Nutritional and Economic Aspects of Feed Utilization by Dairy Cows p. 51 [C. R. Hoglund, G. L. Johnson, C. A. Lassiter and L. D. McGilliard, editots]. Ames: Iowa State College Press.

Miller, D. S. \& Payne, P. R. (1964). Proc. Nutr. Soc. 23, xi.

Munro, H. N. (1964). Proc. Nutr. Soc. 23, 1 .

Murdoch, J. C. (1962). F. Br. Grassld Soc. 17, 268.

Ørskov, E. R., MacDonald, I., Fraser, C. \& Corse, E. L. (197 I). F. agric. Sci., Camb. 77, 35 I.

Paquay, R., De Baere, R. \& Lousse, A. (1972). Br. F. Nutr. 27, 27.

Reid, J. T., Moe, P. W. \& Tyrrell, H. F. (1966). F. Dairy Sci. 49, 215.

Robinson, J. J. \& Forbes, T. J. (1966). Br. $\mathscr{~}$. Nutr. 20, 263.

Robinson, J. J. \& Forbes, T. J. (1967). Br. $¥$. Nutr. 2x, 879.

Robinson, J. J. \& Forbes, T. J. (1970a). Anim. Prod. 12, 95.

Robinson, J. J. \& Forbes, T. J. (1970b). Anim. Prod. 12, 6ог.

Rook, J. A. F. (I96I). Dairy Sci. Abstr, 23, 25 I.

Stobo, I. J. F. \& Roy, J. H. B. (I973). Br. F. Nutr. 3o, I 1 3.

Stobo, I. J. F., Roy, J. H. B. \& Gaston, H. J. (1967). Anim. Prod. 9, 7.

Swan, H. (1969). Feed Forum 4, r.

Sykes, A. R. \& Field, A. C. (1972). F. agric. Sci., Camb. 78, I27.

Tagari, H., Ben Gedalya, D., Shevach, Y. \& Bondi, A. (1971). F. agric. Sci., Camb. 77, 413.

$32(2) 6$ 
Thomson, W. \& Aitken, F. C. (r959). Commonw. Bur. Anim. Nutr. Tech. Commun. No. 20.

Tyrrell, H. F., Moe, P. W. \& Flatt, W. P. (1970). Proc. 5 th Symp. on Energy Metabolism. Vitznau, Switzerland: European Association of Animal Production.

Wiktorsson, H. (1971). F. Dairy Sci. 54, 374. 